\title{
TOREY LAKES, DAURSKY STATE NATURE BIOSPHERE RESERVE, RUSSIA: LONG-TERM CHANGES IN ENVIRONMENTAL PARAMETERS
}

\author{
Ekaterina Yu. Afonina ${ }^{\mathbb{D}}$, Natalya A. Tashlykova $\mathbb{D}$ \\ Institute of Natural Resources, Ecology and Cryology of SB RAS, Russia \\ e-mail:kataf@mail.ru,NatTash2005@yandex.ru
}

Received: 05.11.2020. Revised: 18.02.2021. Accepted: 19.02.2021.

\begin{abstract}
This work presents a case study for the lakes Barun-Torey and Zun-Torey, which have been subject to major changes in water level. Both lakes are located in the territory of the Daursky State Nature Biosphere Reserve (arid steppe zone of the Palaearctic region, South-East Transbaikalia, Russia), in the border area with Mongolia. The Torey lakes are large and shallow. A unique feature of the Torey lakes is their unstable hydrological regime. The water level variation is explained by the periodic filling and drying of the lakes due to cyclical climatic changes in humidity and temperature. A brief overview of some hydrological and hydrochemical characteristics of the lakes, using references and unpublished (own) data, is provided. The lakes have been studied for a number of years, which have been provisionally divided into some periods. There are three periods for Lake Zun-Torey: high (1999 and 2003), intermediate (2007, 2011) and low (2014 and 2016) lake levels, and two periods for Barun-Torey: high water level (1999 and 2003) and the initial filling phase $(2014,2016,2018,2020)$. The aim of this paper is to synthesise data on changes in the environmental parameters of the Torey lakes during a climate cycle (the drying and initial filling of basins). Climatic fluctuations lead to changes on some physical parameters and the hydrochemical compound. In Lake Zun-Torey, such environmental characteristics are total dissolved solids, $\mathrm{pH}$, and water temperature increase, while depth decreases during transitions from high to low water levels. In periods of high water level, the hydrochemical parameters of Lake Barun-Torey are the same as those of Lake Zun-Torey (oligohaline and alkaline). The temporary pools on the dry bed of Lake Barun-Torey are freshwater, arising from groundwater and precipitation.
\end{abstract}

Key words: abiotic parameters, Daursky State Nature Biosphere Reserve, hydrological cycle, Lake BarunTorey, Lake Zun-Torey, water level

\section{Introduction}

Salt lakes are geographically widespread, numerous and a significant part of the world's inland aquatic ecosystems (Hammer, 1986). They are important natural assets with considerable aesthetic, cultural, economic, recreational, scientific, conservation and ecological values (Zadereev, 2018). Saline lakes develop as the termini of inland drainage basins where hydrological inputs and outputs are balanced. These conditions occur in arid and semi-arid regions (Williams, 2002). Shallow soda lakes attract considerable attention because of their variable and individualistic nature (Egorov, 1993; Tóth et al., 2014; Schagerl, 2016; Boros \& Kolpakova, 2018), and are sensitive to environmental changes, especially changes in the precipitation and strongly dependent on the hydrological budget. Alternation of dry and wet periods causes changes in the physical (water temperature, water level), and chemical (extensive seasonal and inter-annual variations in salinity and $\mathrm{pH}$ ) characteristics of such a lake (Comín et al., 1992; García et al., 1997; Shadrin \& Anufriieva, 2013).
Dauria, located in the northern part of Central (Inner) Asia, is counted among those regions which ecological state is particularly dependent on climatic change. Most of the Daurian ecoregion lies in the north and northeast of China and Eastern Mongolia but it also includes the Russian forest-steppe and steppe regions of the Zabaikalsky Kray and the Republic of Buryatia (Kirilyuk \& Tkachuk, 2012). Dauria is characterised by intrasecular cycles, lasting from $8-10$ to 35 years. The last complete cycle of changes in atmospheric moisture regime in this territory lasted 34 years (from 1965 to 1998) and had equal periods of aridity (to 1981) and humidity (Zamana \& Borzenko, 2010; Bazhenova, 2013). From 1982 to 2009, the phase with a large amount of precipitation corresponded to the phase of relatively low temperatures, and, conversely, the dry phase of the precipitation regime corresponded to relatively high temperatures (Obyazov, 2012).

The amazingly rich and diverse ecosystems of the Daurian steppe are concentrated in the Daursky State Nature Biosphere Reserve, 
which facilitates the preservation of dozens of rare species and the study of many natural processes of the great steppe. Daursky State Nature Biosphere Reserve was created in 1987 to preserve and study the steppe, lacustrine-steppe and wetland complexes of Transbaikalia. The Daursky State Nature Biosphere Reserve is the only place in Russia where such unique species as the Relict Gull and the gazelle survive (Kirilyuk et al., 2009). The Daursky State Nature Biosphere Reserve forms part of a key bird area in Asia, being one of the most important resting places for millions of migratory waterfowl and semi-aquatic birds (Goroshko, 2000). The Daursky State Nature Biosphere Reserve, together with the Chinese and Mongolian reserves, forms an international Protected Area named «Dauria». Extreme dynamics and a low level of anthropogenic alteration to its natural systems are both important characteristics of the Daursky State Nature Biosphere Reserve (Kirilyuk et al., 2009).

The lakes Zun-Torey and Barun-Torey are the largest hydrological objects of the Daursky State Nature Biosphere Reserve zone. They are the remains of a large lake (sea) which once reached the size of $2400 \mathrm{~km}^{2}$ (Shamsutdinov, 1983). Frish (1972) stated almost 50 years ago «In a few years, one can observe phenomena, the development of which in other places is known to exceed the human life span». Therefore, in the current context of the climate emergency, this area represents a testing ground for observing climatic changes and how various communities (terrestrial and aquatic) respond and adapt to these changes (Kuklin et al., 2013). A careful study of the nature of the Torey lakes (the standard for a variety of landscape transformations) may suggest how people can interact appropriately with the landscape in other regions (Frish, 1972). The pulsating water regime of the lakes determines the cyclicity of the terrestrial ecosystems (Kirilyuk et al., 2009,2012 ) and periodic surges in the productivity of the aquatic ecosystems in the shallow soda lake (Afonina \& Tashlykova, 2019, 2020; Bazarova et al., 2019).

The limnology of Torey soda lakes, despite their extensive area, has not been well studied. Even so, some authors have contributed to our knowledge of them (e.g. Ivanov, 1977; Alimov, 1991; Dzyuba \& Kulagina, 2005; Tsyrenova et al., 2008; Namsaraev, 2009; Zakharyuk et al.,
2010; Sklyarov et al., 2011). In this paper, we use long-term data from two lakes to document how changes in water level have affected physical and chemical variables in these water bodies. Our aim is to synthesise data on changes in the environmental parameters of the Torey lakes during a climate cycle, the drying and initial filling of basins. Studies of contemporary responses of lakes to climate shifts are of interest for planning and management (Olaka et al., 2010; Jeppesen et al., 2015). So this work is important and particularly important because the study area is becoming increasingly arid, and this trend is expected to continue under the current climate-change scenario (Obyazov, 1996).

\section{Material and Methods Study site description}

The Daursky State Nature Biosphere Reserve belongs to the Onon-Torey district of the dry Mongolian-Manchurian steppe, which is the northeastern part of the Central Asian physicalgeographical region. Torey lakes are large in area and shallow; they constitute of one hydrological system and are connected by an Utochi channel (about $300 \mathrm{~m}$ long and $100 \mathrm{~m}$ wide) (Fig. 1).

A unique feature of the lakes Barun-Torey and Zun-Torey is the unstable hydrological regime. The reason for the water level change is the periodic filling and drying of lakes due to cyclic climatic changes in humidity and temperature. Over the past 200-220 years, the lakes repeatedly dried up and filled up with a frequency of about 30 years (Obyazov, 1996) (Fig. 2).

The water level regime of Lake Zun-Torey differs from that of Lake Barun-Torey, since its catchment area is smaller and it has no surface tributaries. When the water level is high, the hydrological regime in the lakes is similar, and they are connected by a channel. The runoff from Lake Barun-Torey to Lake Zun-Torey begins at the level of $596.1 \mathrm{~m}$ a.s.1. according to the Baltic system (BS). Once the water surface of the lakes is level up, the direction of the current in the channel changes under the influence of wind and other factors. When the water level falls, the shallower Lake Barun-Torey dries up quicker, and the water begins to move in the opposite direction through the connecting channel: from Lake Zun-Torey to Lake BarunTorey. With a further fall in the water level the Utochi channel dries up and the lakes become isolated again (Obyazov, 1996). 


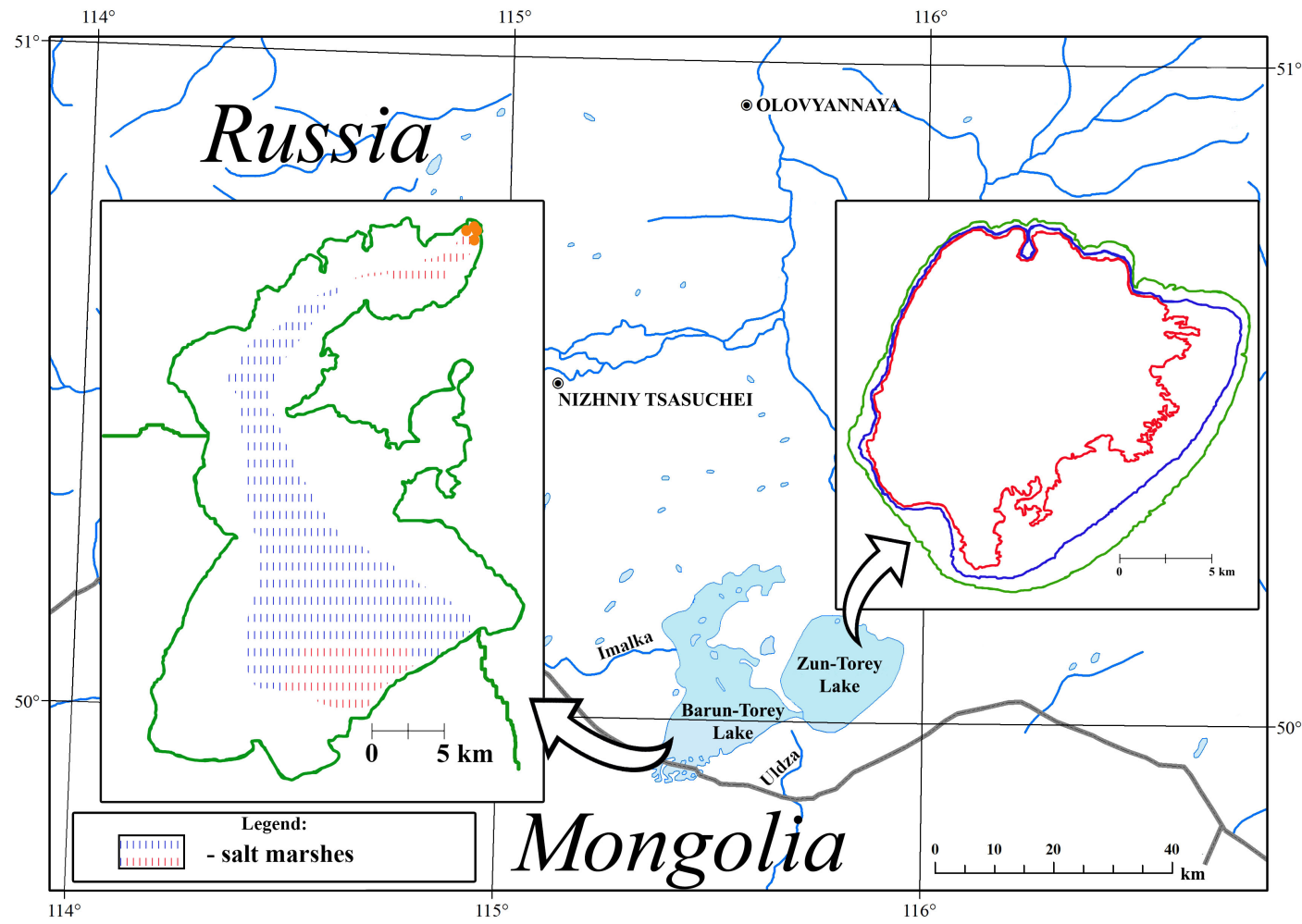

Fig. 1. Geographic location of the Torey lakes (Transbaikalia, Russia) and its changing surface area during various water level periods. Designations: green - high water level; blue - intermediate water level; red - low water level; orange - initial filling phase.

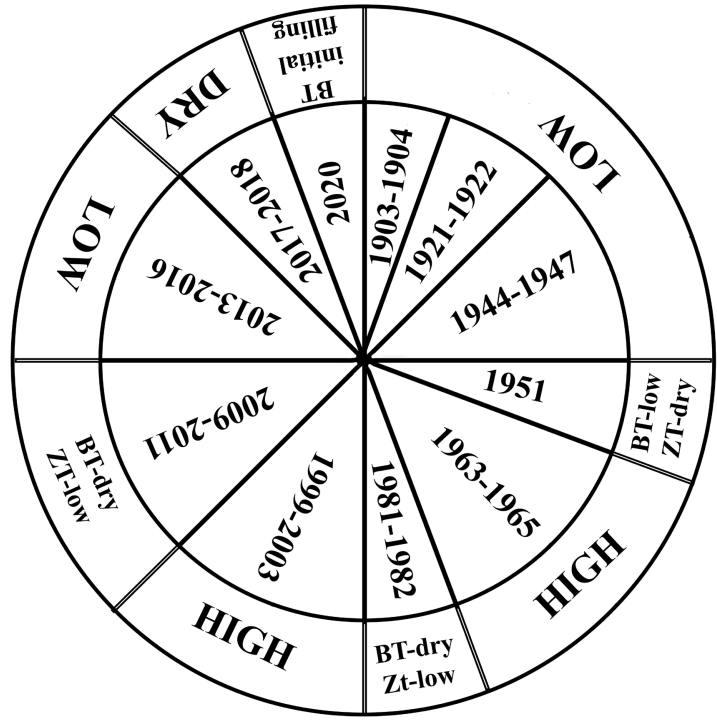

Fig. 2. Timeline of the depression state in Lake Zun-Torey (ZT) and Lake Barun-Torey (BT) according to Frish (1972), Krendelev (1986), Obyazov (2012), Bazhenova (2013), and our data.

In high water years with a water cut of $598 \mathrm{~m}$ a.s.l. BS, the surface area of Lake Barun-Torey reaches 550 $\mathrm{km}^{2}$, the volume is $1.4 \mathrm{~km}^{3}$, the length is $40 \mathrm{~km}$, the width is $20 \mathrm{~km}$, the maximum depth is $4.3 \mathrm{~m}$, and the average depth is $2.5 \mathrm{~m}$. The catchment area is 25700 $\mathrm{km}^{2}$. There are approximately ten islands in the lake, and their number varies depending on the water level. The bottom of the lake is flat, and the deepest parts are in the centre of the lake. The shoreline is crenelated, with abundant headlands and bays. The shores are slightly swampy, often saline lands occupy (Kirilyuk et al., 2009, 2012; Kirilyuk \& Tkachuk, 2012). According to Vakhnina et al. (2020), in 1999 the maximal lake area reached $557.8 \mathrm{~km}^{2}$. Two rivers flow into the lake, of which the River Uldza flows up from the south and forms a vast estuary, while the River Imalka flows into the lake from the west. The main catchment area of the rivers is located in Mongolia. The outflow only occurs in high water years, while in dry years the riverbeds dry up. For this reason, and for the associated decrease in precipitation, the lake quickly becomes shallow, and its surface area shrinks, sometimes resulting in the lake drying up completely (Kirilyuk et al., 2009, 2012). By June 2009, Lake Barun-Torey had completely dried up while just before its floor contained only shallow large puddles, which appeared after rains (Kirilyuk et al., 2009). A trend was noted in 2013 that the lake was filling, in connection with the hiatus in the Pacific monsoon. In the summer of 2014, a flow was recorded in the River Uldza. But in the spring of 2015, the Lake Barun-Torey could not recover its water, and, as a result, the lake dried out again (Davydova, 2014). According to our observation, in the summers of 2014, 2016, 2018, 2020, the dry bed of Lake Barun-Torey was a steppe with some small water bodies (pools, puddles) (Fig. 3). In autumn 2020, we observed the discharge of a full-flowing River Uldza into the Lake Barun-Torey (Fig. 4). 


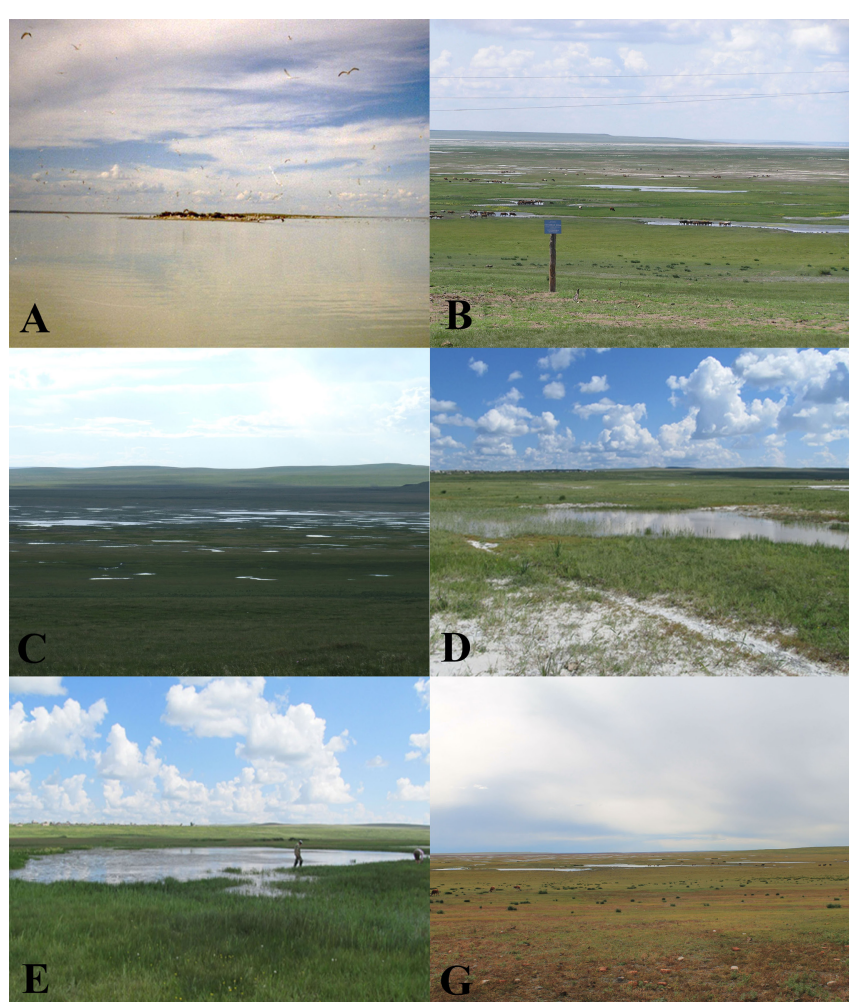

Fig. 3. Lake Barun-Torey in various years. Designations: A - 1999 (Photo: G. Tsybekmitova), B - 2011 (Photo: G. Tsybekmitova), C - 2014 (Photo: P. Matafonov), D - pool 3 (puddle) in 2018 (Photo: B. Bazarova), E-pool 4 (Photo: B. Bazarova), G-2020 (pools 1 and 2 are visible in the distance) (Photo: Sh. Askarov).

Lake Zun-Torey is round, with a weakly indented shoreline and a single island, which turns into a peninsula when the water level lowers. When the water is high, the surface area of this lake is $285 \mathrm{~km}^{2}$, the volume is $1.6 \mathrm{~km}^{3}$, the length is $23 \mathrm{~km}$, the width is $13 \mathrm{~km}$, the maximum depth is $6.7 \mathrm{~m}$, and the average depth is $4.5 \mathrm{~m}$. The highest depth is in the northern part of the lake, and the lake bed drops steeply. The catchment area is $26000 \mathrm{~km}^{2}$ (Kirilyuk et al., 2009, 2012). In 1999 the maximal lake area was $301.6 \mathrm{~km}^{2}$ (Vakhnina et al., 2020). When low water level, the only island connects to the mainland coast. There were wide mud bars, sandy and pebble beaches around the lake (Kirilyuk et al., 2012). In 2015, the lake area reached $254 \mathrm{~km}^{2}$ (Vakhnina et al., 2020). Lake Zun-Torey completely dried out in autumn 2017. According to our observation, in 2018, the lake formed viscous impassable salt marshes with precipitation water, driven by winds to different lake shores. In 2020, the Lake Zun-Torey was a steppe where gazelle antelopes were grazing (Fig. 5).

Torey lakes are soda-chloride-sodium lakes with a high alkalinity. The lakes' hydrochemistry is determined by a combination of an evaporative concentration of salt composition, the production of organic matter and by hydrogenic sedimentation (Zamana, 2009; Zamana \& Borzenko, 2010).

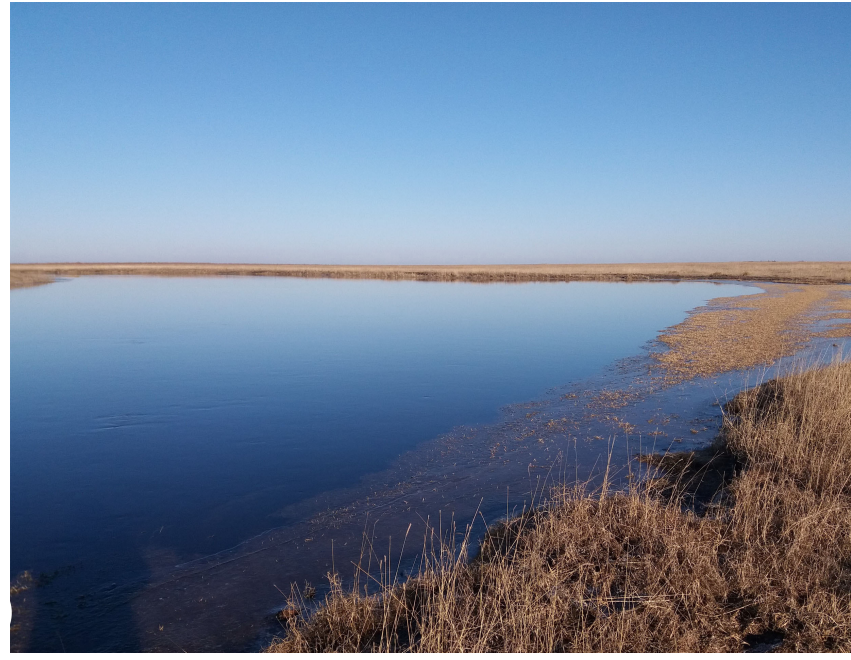

Fig. 4. River Uldza in 2020 (Photo: E. Afonina).

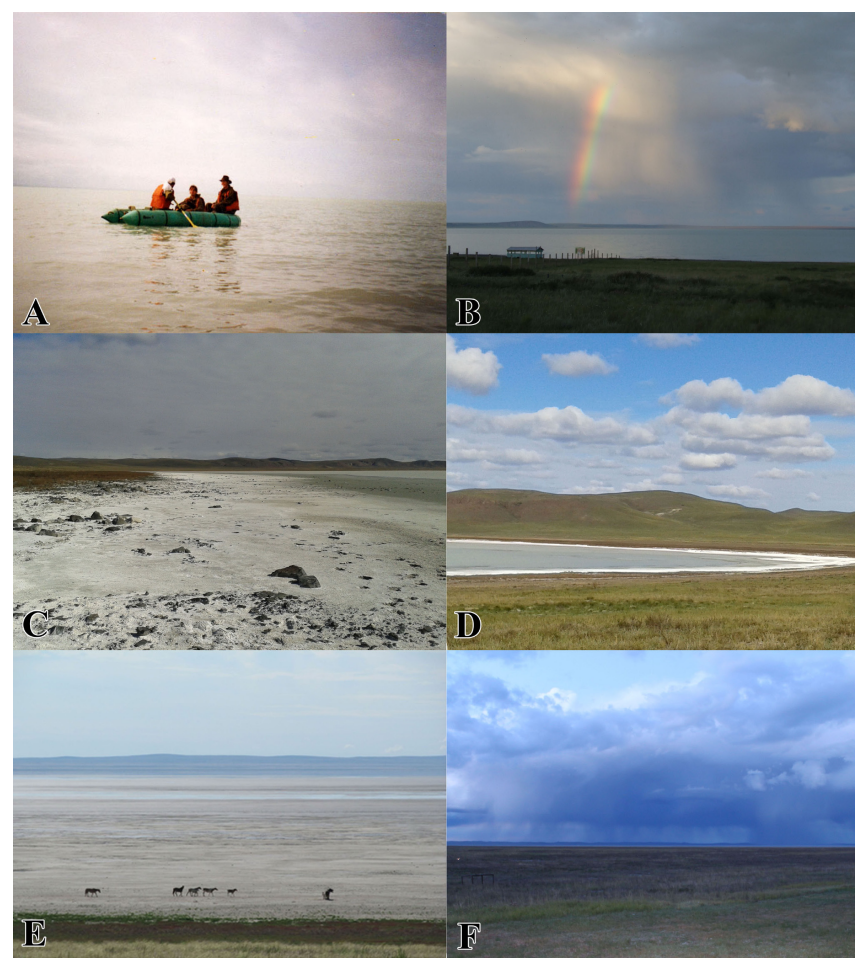

Fig. 5. Lake Zun-Torey in various years. Designations: A 1999 (Photo: E. Afonina), B - 2014 (Photo: P. Matafonov), C, D-2016 (Photos: G. Tsybekmitova), E-2018 (Photo: B. Bazarova), F - 2020 (Photo: Sh. Askarov).

\section{Data sampling and analysis}

We present a case study for the lakes BarunTorey and Zun-Torey, which have been subject to major changes in water level. We have provided a brief overview of the characteristics of the lakes and add detailed information using unpublished data. We have been studying the lakes for a number of years, which we have provisionally divided into periods, including three periods for the Lake Zun-Torey (high (1999 and 2003), intermediate $(2007,2011)$ and low $(2014$ and 2016) lake levels) and two periods for Lake Barun-Torey (high water level (1999 and 2003) 
and the initial filling phase $(2014,2016,2018$, $2020)$ ). For the majority of the studies (19992016), the methods used are described in detail by Tsybekmitova \& Belozertseva (2014), Tsybekmitova (2018), Afonina \& Tashlykova (2018, 2019, 2020), Bazarova et al. (2019).

In 2018 and 2020 (unpublished data), we used an Aquaread multiparametric sensor for water analysis (Great Britain) to determine the total of dissolved solids (TDS), $\mathrm{pH}$, dissolved oxygen content, and water temperature. The abiotic parameters were measured at the surface of the pools. The water transparency was determined with a standard Secchi disk.

We used parametric and multivariate statistical analysis to classify the lakes according to the similarity of the major abiotic variables using XLSTAT Basic package (Addinsoft, USA). Variables included in the abiotic parameter matrix were normalised, with preliminary selective transformation of the initial values. Similarity in terms of sets of abiotic factors was estimated using normalised values of Euclidean distance based on hierarchical clustering and ordination (Dalgaard, 2008). We performed a principal correspondence analysis (PCA) for the water body groups and environmental variables using pooled sampling data.

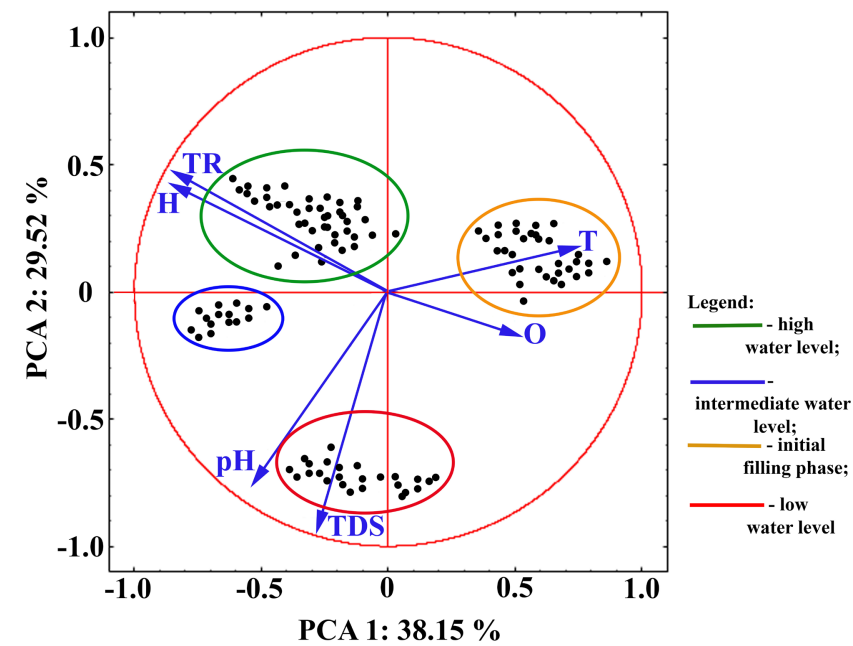

Fig. 6. Vector projections on the planes of two main components - PCA1 and PCA2. The used parameters and designations: $\mathrm{H}-$ depth, TR - water transparency, $\mathrm{pH}, \mathrm{T}$ - water temperature, $\mathrm{O}$ - dissolved oxygen content, TDS - total dissolved solids.

\section{Results}

The first two components in the results of the PCA explained $67.67 \%$ of the variance in total (Table). The PCA performed with PCA divided the studied lakes and pools into four groups according water level and basic abiotic parameters (Fig. 6).

The first group of sites consists of lakes Barun-Torey and Zun-Torey in high water level, when depth $(\mathrm{r}=-0.806, \mathrm{p}<0.001)$ and transparency $(r=-0.827, p<0.001)$ were the highest. The second and third group include Lake Zun-Torey during intermediate and low water level respectively. In low lake water levels TDS ( $\mathrm{r}=-0.990$, $\mathrm{p}<0.001)$ and $\mathrm{pH}(\mathrm{r}=0.600, \mathrm{p}<0.001)$ were the highest. In the fourth group, filling pools located on the Lake Barun-Torey dry bottom, water temperature $(\mathrm{r}=0.510, \mathrm{p}<0.001)$ and dissolved oxygen contents $(\mathrm{r}=0.355, \mathrm{p}<0.001)$ increased.

\section{Lake Zun-Torey}

In high water years (1999 and 2003), the maximal sampling depth was $6.5 \mathrm{~m}$ and $5.6 \mathrm{~m}$ respectively, the water transparency was $0.5 \mathrm{~m}$. Abiotic parameters corresponded to TDS $=2.12$ $\mathrm{g} \times 1^{-1}, \mathrm{pH}=9, \mathrm{~T}=20.4-23.4^{\circ} \mathrm{C}, \mathrm{O}_{2}=5.6 \mathrm{~g} \times 1^{-1}$. In intermediate water level years (2007 and 2011), the maximal sampling depth was $2.3 \mathrm{~m}$ and $1.7 \mathrm{~m}$ respectively. The water transparency was $0.3 \mathrm{~m}$. TDS increased to 5.1-8.2 $\mathrm{g} \times 1^{-1}, \mathrm{pH}$ to $9.4-9.6$, and water temperature to $23-24^{\circ} \mathrm{C}$. Dissolved oxygen content changed from 4.8 $\mathrm{g} \times 1^{-1}$ to $7.0 \mathrm{~g} \times 1^{-1}$. In low water years (2014 and 2016), the maximal sampling depth was $1.5 \mathrm{~m}$ and $0.5 \mathrm{~m}$ respectively. The water transparency was $0.2-0.3 \mathrm{~m}$. TDS increased to $14-21 \mathrm{~g} \times \mathrm{1}^{-1}$, $\mathrm{pH}$ to 9.9 , and water temperature to $26.5^{\circ} \mathrm{C}$. Dissolved oxygen content increased to $7.8-10.3$ $\mathrm{g} \times \mathrm{1}^{-1}$ (Fig. 7). The water in the lake was an albescent colour (Fig. 5, Fig. 7).

\section{Lake Barun-Torey}

In 1999 and 2003 the maximal sampling depth was $4.5 \mathrm{~m}$ and $3 \mathrm{~m}$ respectively. The water transparency was $0.4 \mathrm{~m}$ and $0.3 \mathrm{~m}$ respectively. Abiotic parameters corresponded to TDS $=2.1 \mathrm{~g} \times \mathrm{l}^{-1}$, $\mathrm{pH}=9, \mathrm{~T}=20.5-24^{\circ} \mathrm{C}, \mathrm{O}_{2}=14.4 \mathrm{~g} \times \mathrm{1}^{-1}$. The water was an albescent colour (Fig. 3A, Fig. 8).

Table. Results of component analysis of the summarised data

\begin{tabular}{|c|c|c|c|}
\hline Main components & Eigenvalue & Constrained inertia (\%) & Cumulative (\%) \\
\hline 1 & 2.29 & 38.15 & 38.15 \\
\hline 2 & 1.77 & 29.52 & 67.67 \\
\hline
\end{tabular}



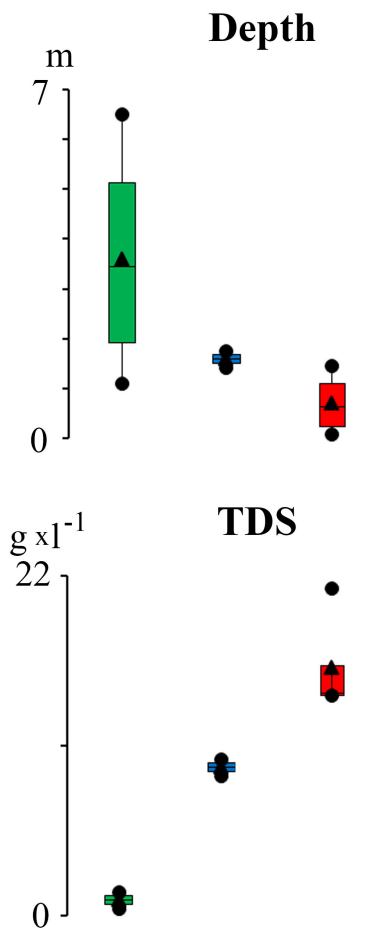

$\Delta$ - mean
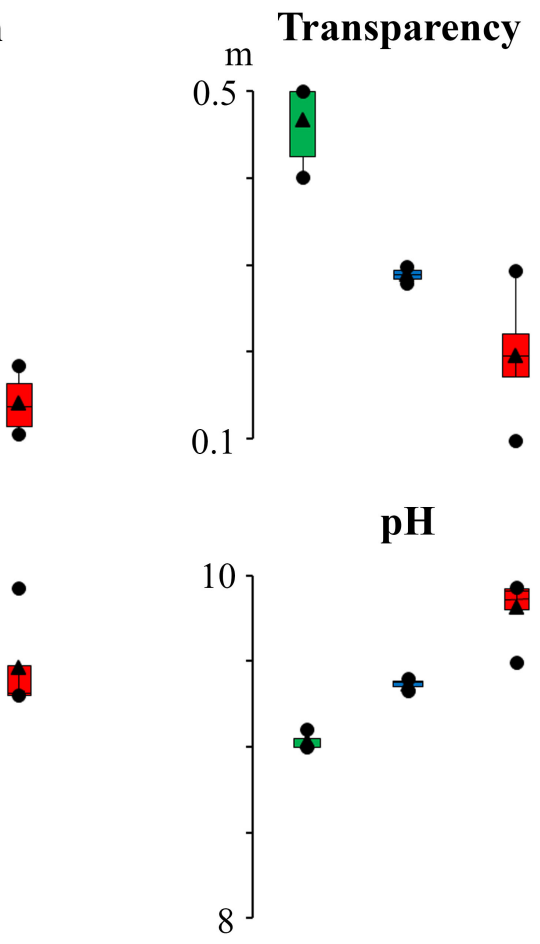

- maximum/ minimum
Temperature
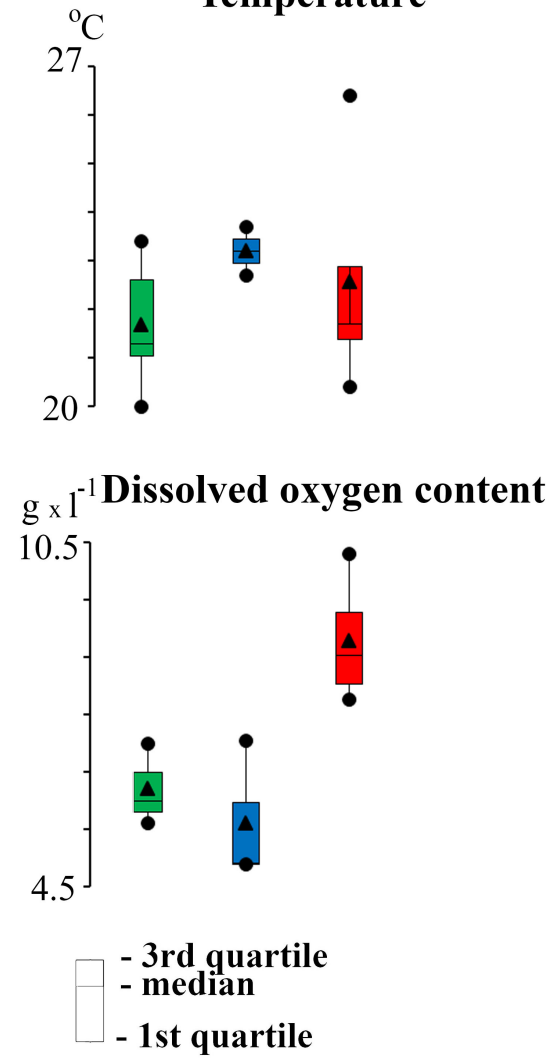

Fig. 7. Box and whiskers plot of changes in environmental variables of the Lake Zun-Torey in various water levels. Designations: green - high water level; blue - intermediate water level; red - low water level.

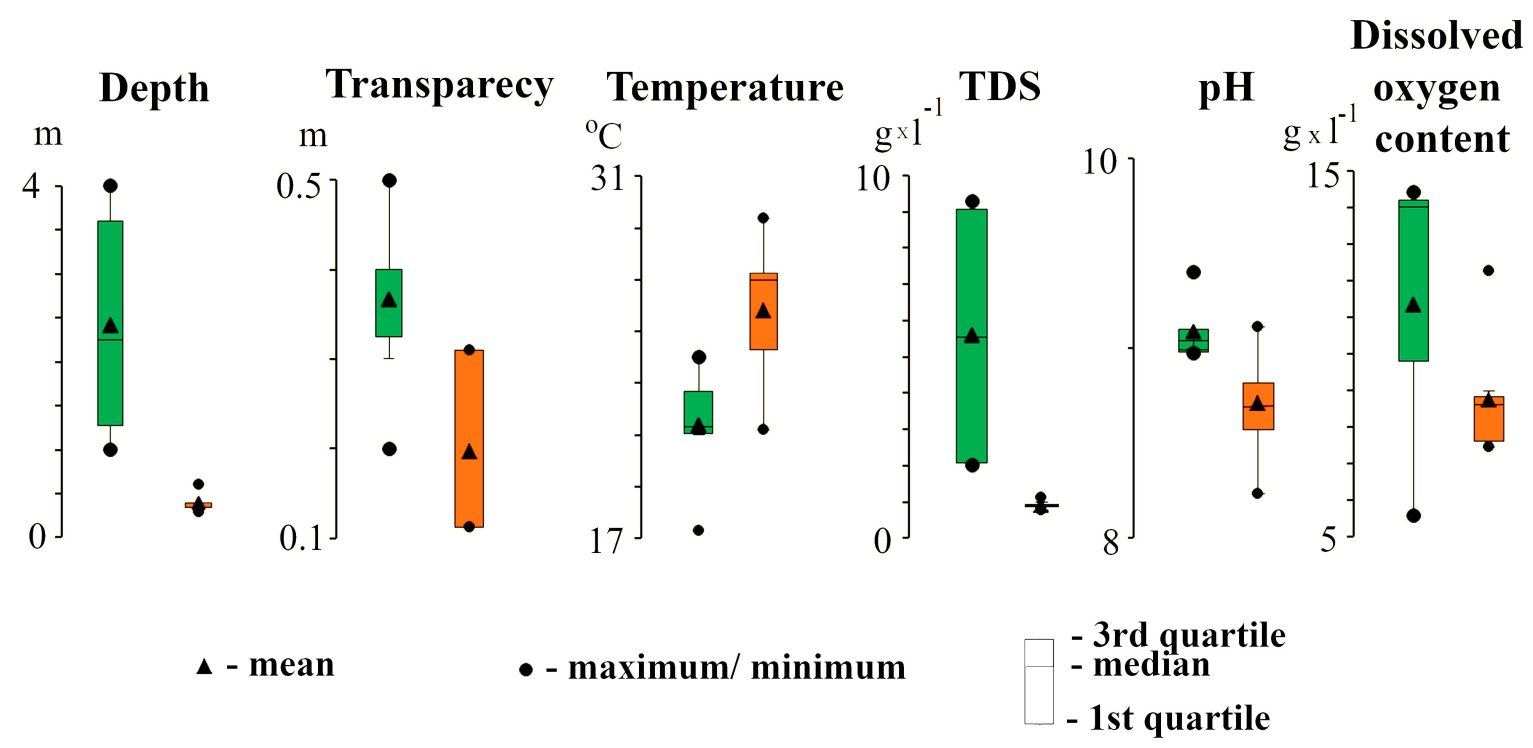

Fig. 8. Box and whiskers plot of changes in environmental variables of the Lake Barun-Torey in various water levels. Designations: green - high water level; orange - initial filling phase.

Temporary pools on the Lake Barun-Torey bed

Since 2014 at the northernmost point of Lake Barun-Torey dry bed (near the village of Kulusutai) we have observed some small water bodies (pools and/or puddles) with an area of $10-100 \mathrm{~m}^{2}$ and a depth of about $0.1-0.5 \mathrm{~m}$. In common the filling small temporary pools on the Lake Barun-Torey dry bed were characterised as alkaline $(\mathrm{pH}=8.2-9.0)$, oligohaline $(0.5-1.0$ $\left.\mathrm{g} \times 1^{-1}\right)$, well warmed up $\left(26-30^{\circ} \mathrm{C}\right)$, and muddy (except pool 3) $(\mathrm{TR}=0.1-0.3 \mathrm{~m})($ Fig. 8).

Temporary pool 1 and pool 2 are fed by a groundwater discharge through the fracture at the western shore of the lake. We observed aquatic plants (Lemna spp., Potamogeton spp., Phragmites australis (Cav.) Trin. ex Steud.) and filamentous algae in the pools. The bottom of the pools were primarily muddy and were homo- 
geneous throughout, with a depth of soft silt of $0.1-0.15 \mathrm{~m}$. The water was grey-brown. Pools are used as a watering place for farm animals. In autumn 2020, we noted that the pool areas had increased to $100-150 \mathrm{~m}^{2}$ (Fig. 3G).

Pool 3 is a seasonal puddle. It is formed in the relief deepening as a result of precipitation. Semiaquatic plants (e.g. Phragmites australis) grew along the pool perimeter. Bottom sediments were dense. The water was an albescent colour (Fig. 3D).

Pool 4 is a type of pool originated from differential thawing along cracks in the permafrost. Submerged and semi-submerged plants (Charales, Potamogeton spp.) completely covered the pool bottom, and Phragmites australis thickets grew nearshore. Meadow plants were well developed around the pool. The water was light and clear. No animal traces were observed (Fig. 3E).

\section{Discussion}

Soda lakes with a high surface to volume ratio respond strongly to climatic changes (Olaka et al., 2010). In shallow lakes, the water level fluctuates naturally intra- and inter-annually depending mostly on the regional climatic conditions (Beklioglu et al., 2007). In this inland and fluctuating environment, acute changes in the physical and chemical environment occur throughout each hydrological cycle. Moreover, the duration of each cycle is different. Several aspects of the cycles have been studied, which alternate between wet and dry phases of inter-annual and seasonal environments (Jeppesen et al., 2015). In Southeastern Transbaikalia, in 1951-2009, the average annual temperature increased by $1.9^{\circ} \mathrm{C}$. In different parts of the study area, the linear trend showed increases from $1.5^{\circ} \mathrm{C}$ up to $2.2^{\circ} \mathrm{C}$ during 59 years. It led to an increase of the period with positive temperatures from 165-167 days to 173179 days. Long-term changes in precipitation are cyclic. In the study area, cycles are most vividly apparent within the time span of a century (Obyazov, 1994). From 1955 to 1963, there was a period with above average precipitation, followed, up to 1982 , by a below average period. In 1983, a wet period started again, lasting until 1998. The beginning of a new dry period was in 1999. This period probably ended by 2012 . Thus, up to two full cycles in precipitation occurred in the area over the past 60 years. The lake levels also directly depend on precipitation and correlate with river flows (Simonov et al., 2013). Changes in climate in the Daurian ecoregion, especially with regard to humidification cycles and continuing warming, caused alterations in habitats, and even habitat disappearance (Kirilyuk \& Tkachuk, 2012). In the lakes Barun-Torey and Zun-Torey, the salt layer that has been formed after a period of drying is gradually becoming overgrown and turning into meadow and steppe. The lake depression is devoid of water, and instead of being an ecosystem inhabited by aquatic organisms and organisms that live near water, including thousands tons of fish, it has become part of the terrestrial ecosystem (Kirilyuk et al., 2012).

In Lake Zun-Torey, the salinity varied from oligohaline $\left(2.1 \mathrm{~g} \times 1^{-1}\right.$ in 1999) to polyhaline (20.9 $\mathrm{g} \times \mathrm{1}^{-1}$ in 2016), and the $\mathrm{pH}$ increased from 9.0 to 9.9 respectively during transitions from high to low water levels. The decrease in the heat capacity of the lake, caused by the increase in salinity, resulted in a rapid, strong heating of the water in the summer months (water temperature rose from $20.4-23.4^{\circ} \mathrm{C}$ to $21.4-26.4^{\circ} \mathrm{C}$ ). The considerable area of Lake Zun-Torey at shallow depths promoted wind mixing of the water mass and its saturation with oxygen (dissolved oxygen increased from $5.6 \mathrm{~g} \times 1^{-1}$ to $\left.8.6 \mathrm{~g} \times \mathrm{1}^{-1}\right)$ (Afonina \& Tashlykova, 2019).

About Lake Barun-Torey, unfortunately, we have no material to characterise the intermediate water level period. But according to Zamana \& Borzenko (2010) in 2006 TDS was $9.7 \mathrm{~g} \times \mathrm{1}^{-1}$ and the water type was characterised as mesohaline. The lake drain rather quickly after the river inflow ceases. Not far from springs, gushing out of the ground, there are small freshwater lakes and small ponds with bitter salt water. The exposed bottom of the lake (no longer underwater) is covered with a variety of rather sparse vegetation (Nekipelov, 1957; Simonov et al., 2013). An increase in atmospheric precipitation, due to the penetration of the Pacific monsoons into south-eastern Transbaikalia, along with the release of groundwater and the melting of permafrost, has led to the initial and partial filling of Lake Barun-Torey (Zamana \& Vakhnina, 2014). The studied temporary pools located on the dry bed of Lake Barun-Torey show marked differences among one another, although they are all temporary, shallow and fresh systems (up to $1.0 \mathrm{~g} \times 1^{-1}$ ). Temporary pool 1 and pool 2 are fed by groundwater discharge through the fracture at the western shore of the lake. The piezometric level of the studied water seepage is at a depth of $4 \mathrm{~m}$ and is above the earth surface (Borzenko et al., 2019, 2020). 
The sensitivity of the water level to variations in climate depends on the bathymetry of lake basins, evaporation rates, and the interannual variability of water inflows (Wood \& Talling, 1988; Talling, 2001). Periodic changes in the level of surface and ground water are noted in other endorheic shallow lakes in Russia (Vesnina et al., 2012; Vizer, 2016), China (Deng et al., 2001), Mongolia (Rasskazov et al., 1990; Sevastyanov, 2000), Europe (Comín et al., 1999; Legler et al., 2011), Africa (Schagerl, 2016), and North America (Stephens, 1990). In the dry period, the lakes completely dry up, while in the high-water period they are stable and filled with water. We would also like to note that among large alkaline water bodies vulnerable to climate change only one other lake, in Africa, has a 30-year hydrological cycle like the Torey lakes (Olaka et al., 2010; Schagerl, 2016).

Saline lakes in Central Asia provide numerous ecosystem services and have a high and often underestimated economic value (Zadereev et al., 2020). We believe that our work on the review of available literature and along with own data supports the sensitive and rare soda lakes. Soda aquatic ecosystems in arid regions are important habitats for aquatic, semiaquatic, and riparian wildlife. These habitats serve as a regional biodiversity source. Because of the variability of local, regional, and global climate, these lakes fluctuate in size and salinity and support a regional pool of species adapted to various levels of salinity (Kirilyuk et al., 2009; Kirilyuk \& Tkachuk, 2012; Zadereev et al., 2020). Lake Barun-Totey and Lake Zun-Torey provide cultural ecosystem services. They have a symbolic meaning. Lakes are used for commercial fishery at the high water level. The Torey lakes are used as a recreational site for summer camping and fishing. A cattle grazing is the main land-uses in the catchment. Educational and scientific services are the most important ecosystem services of the Torey lakes, which are used as valuable science research object. The climate change is expected to have a severe impact on the Torey lakes provision of ecosystem services. A reduced runoff, increased evaporation, and an increased climate variability form the most important impact of climate change on the lakes.

\section{Conclusions}

In the regressive water phase of the climatic cycle (the drying and initial filling of basins), the water level falls in the lakes. This leads to changes in some physical parameters and hydrochemi- cal compounds. In Lake Zun-Torey, we found an increase in such environmental characteristics as TDS (from $2.1 \mathrm{~g} \times 1^{-1}$ to $20.9 \mathrm{~g} \times 1^{-1}$ ), $\mathrm{pH}$ (from 9.0 to 9.9 ), dissolved oxygen concentration (from $5.6 \mathrm{~g} \times \mathrm{1}^{-1}$ to $8.6 \mathrm{~g} \times \mathrm{1}^{-1}$ ), and temperature (from $20.4-23.4^{\circ} \mathrm{C}$ to $21.4-26.4^{\circ} \mathrm{C}$ ), and decrease in depth (from $6.5 \mathrm{~m}$ to $0.5 \mathrm{~m}$ ) during transitions from high to low water levels. In a period of high water level, the water of Lake Barun-Torey is of the same constitution as in Lake Zun-Torey (oligohaline and alkaline). The temporary pools on the dry bed of Lake Barun-Torey are freshwater, arising from groundwater and precipitation.

\section{Acknowledgements}

We would like to thank our colleagues at the Laboratory of Aquatic Ecosystems (Institute of Natural Resources, Ecology and Cryology of SB RAS, Russia) for their assistance in collecting samples. We are grateful to the staff of the Daursky State Nature Biosphere Reserve (V.E. Kirilyuk, O.K. Kirilyuk, O.A. Goroshko, A.A. Cherepitsyn, A.P. Borodin) for organising field research. We thank P.V. Matafonov, G.Ts. Tsybekmitova, B.B. Bazarova, Sh.A. Askarov for some photos provided. This study was supported by the Program for Basic Research of the Siberian Branch of the Russian Academy of Sciences, project no. FUFR-2121-0006. Authors are grateful to the anonymous reviewers and editors for having substantially improved this manuscript with their comments and advice.

\section{References}

Afonina E.Yu., Tashlykova N.A. 2018. Planktonic communities in the Torey Lakes (Zabaikalsky Krai) in a low water year. Journal of Siberian Federal University. Biology 11(4): 306-320. DOI: 10.17516/1997-1389-0074

Afonina E.Yu., Tashlykova N.A. 2019. Plankton of saline lakes in Southeastern Transbaikalia: transformation and environmental factors. Contemporary Problems of Ecology 12(2): 155-170. DOI: 10.1134/ S1995425519020021

Afonina E.Yu., Tashlykova N.A. 2020. Fluctuations in plankton community structure of endorheic soda lakes of southeastern Transbaikalia (Russia). Hydrobiologia 847(6): 1383-1398. DOI: 10.1007/s10750-020-04207-Z

Alimov A.F. (Ed.). 1991. Soda lakes of Transbaikalia: Ecology and productivity. Novosibirsk: Nauka. 216 p. [In Russian]

Bazarova B.B., Tashlykova N.A., Afonina E.Yu., Kuklin A.P., Matafonov P.V., Tsybekmitova G.Ts., Gorlacheva E.P., Itigilova M.Ts., Afonin A.V., Butenko M.N. 2019. Long-term fluctuations of the aquatic ecosystems in the Onon-Torey plain (Russia). Acta Ecologica Sinica 39: 157-165. DOI: 10.1016/j.chnaes.2018.08.003

Bazhenova O.I. 2013. Modern dynamics of lake-fluvial systems of Onon-Torey high plain (Southern Transbaika- 
lia). Bulletin of Tomsk State University 371: 171-177. [In Russian]

Beklioglu M., Romo S., Kagalou I., Quintana X., Bécares E. 2007. State of the art in the functioning of shallow Mediterranean lakes: workshop conclusions. Hydrobiologia 584(1): 317-326. DOI: 10.1007/s10750-007-0577-x

Boros E., Kolpakova M. 2018. A review of the defining chemical properties of soda lakes and pans: an assessment on a large geographic scale of Eurasian inland saline surface waters. PLOS ONE 13(8): e0202205. DOI: 10.1371/journal.pone.0202205

Borzenko S., Drebot V., Fedorov I. 2019. Chemical composition and formation conditions of NaHCO3 type of waters in the eastern Transbaikalia. E3S Web of Conferences 98: 01005. DOI: 10.1051/e3sconf/20199801005

Borzenko S., Drebot V., Fedorov I. 2020. Main formation conditions of soda-type groundwater: A case study from south-eastern Transbaikal region (Russia). Applied Geochemistry 123: 104763. DOI: 10.1016/j.apgeochem.2020.104763

Comín F.A., Cabrera M., Rodó X. 1999. Saline lakes: integrating ecology into their management future. Hydrobiologia 395-396: 241-251. DOI: 10.1023/A:1017014023505

Comín F.A., Rodó X., Comín P. 1992. Lake Gallocanta (Aragon, NE Spain), a paradigm of fluctuations at different scales of time. Limnetica 8: 79-86.

Dalgaard P. 2008. Introductory statistics with R. New York: Springer. $364 \mathrm{p}$.

Davydova N.D. 2014. Dynamics of indicators of steppe geosystems of the Southeastern Transbaikalia under the conditions of global climate changes. International Journal of Applied and Fundamental Research 4: 120-125. [In Russian]

Deng W., He Y., Song X.S., Yang B.X. 2001. Hydrochemical characteristics of salt marsh wetlands in western Songnen Plain. Journal of Geographical Sciences 11(2): 217-223. DOI: 10.1007/BF02888693

Dzyuba A.A., Kulagina N.V. 2005. Formation and distribution of mineral lakes of Pribaikalye and Zabaikalye. Water Resources 1: 13-17. [In Russian]

Egorov A.N. 1993. Mongolian salt lakes: some features of their geography, thermal patterns, chemistry and biology. Hydrobiologia 267: 13-21.

Frish V.A. 1972. Torey «experiment». Nature 2: 60-66. [In Russian]

García C.M., García-Ruiz R., Manuel R., Niell F.X., Lucena J. 1997. Hydrological cycle and interannual variability of the aquatic community in a temporary saline lake (Fuente de Piedra, Southern Spain). Hydrobiologia 345(2-3): 131-141. DOI: 10.1023/A:1002983723725

Goroshko O.A. 2000. Key ornithological territories of world importance in the Chita region. In: Inventory, monitoring and conservation of the key ornithological territories of Russia. Vol. 2. Moscow: Russian Bird Conservation Union. P. 19-23. [In Russian]

Hammer U.T. 1986. Saline lake ecosystems of the world. Dordrecht: Springer. 616 p.
Ivanov A.V. 1977. Torey lakes. In: Hydrochemistry of rivers and lakes in a high continental climate Vladivostok: Far East Research Center USSR. P. 69-102.

Jeppesen E., Brucet S., Naselli-Flores L., Papastergiadou E., Stefanidis K., Nõges T., Nõges P., Attayde J.L., Zohary T., Coppens J., Bucak T., Menezes R.F., Freitas F.R.S., Kernan M., Søndergaard M., Beklioğlu M. 2015. Ecological impacts of global warming and water abstraction on lakes and reservoirs due to changes in water level and related changes in salinity. Hydrobiologia 750(1): 201-227. DOI: 10.1007/s10750-014-2169-x

Kirilyuk O.K., Kirilyuk V.E., Goroshko O.A., Saraeva L.I., Sinitsa S.M., Borodin T.I., Tkachenko T.E., Brinich V.A. 2009. Biosphere Reserve "Daursky». Chita: Ekspress. 104 p. [In Russian]

Kirilyuk V.E., Obyazov V.A., Tkachuk T.E., Kirilyuk O.K. 2012. Influence of climate change on vegetation and wildlife in the Daurian ecoregion. In: M.J.A. Werger, M.A. van Staalduinen (Eds.): Eurasian steppes. Ecological problems and livelihoods in a changing world. Dordrecht: Springer. P. 397-424. DOI: 10.1007/97894-007-3886-7 15

Kirilyuk O.K., Tkachuk T.E. 2012. Dauria as an ecological region. In: O.K. Kirilyuk (Ed.). Adaptation to climate change in the river basins of Dauria: ecology and water management. Vol. 5. Chita: Ekspress. P. 7-13. [In Russian]

Krendelev F.P. 1986. Frequency of filling and drying of Torey lakes (South-Eastern Transbaikalia) Doklady Akademii Nauk SSSR 287(2): 396-400. [In Russian]

Kuklin A.P., Tsybekmitova G.T., Gorlacheva E.P. 2013. State of lake ecosystems in Onon-Torei plain in 1983-2011 (Eastern Transbaikalia). Arid Ecosystems 3(3): 122 130. DOI: $10.1134 /$ S2079096113030062

Legler B., Schneider J.W., Gebhardt U., Merten D., Gaupp R. 2011. Lake deposits of moderate salinity as sensitive indicators of lake level fluctuations: Example from the Upper Rotliegend saline lake (Middle-Late Permian, Northeast Germany). Sedimentary Geology 234(1-4): 56-69. DOI: 10.1016/j.sedgeo.2010.11.006

Namsaraev B.B. 2009. Salinity and saline lakes of Transbaikalia: Hydrochemistry, biology. Ulan-Ude: Buryat State University. 332 p. [In Russian]

Nekipelov N.V. 1957. The climate of southeastern Transbaikalia and a historical review of epizootics against the background of climatic changes. Bulletin of Irkutsk Scientific Research Anti-Plague Institute of Siberia and the Far East 15: 19-56. [In Russian]

Obyazov V.A. 1994. Correlation between water filling of the steppe lakes of Transbaikalia and hydrometeorological changes of the Torey lakes. Bulletin of the Russian Geographic Society 126(5): 48-54. [In Russian]

Obyazov V.A. 1996. Regularities of the Transbaikalia steppe zone humidification and their manifestation in the regime of lakes (by the example of Torey lakes). $\mathrm{PhD}$ Thesis Abstract. St. Petersburg. 20 p. [In Russian] 
Obyazov V.A. 2012. Change of climate and hydrological regime of the rivers and lakes in Dahurian ecoregion. In: O.K. Kirilyuk (Ed.): Problems of adaptation and climate change in the river basins of Dahuria: ecological and hydroeconomic aspects. Vol. 5. Chita: Ekspress. P. 24-45. [In Russian]

Olaka L.A., Odada E.O., Trauth M.H., Olago D.O. 2010. The sensitivity of East African rift lakes to climate fluctuations. Journal of Paleolimnology 44(2): 629-644. DOI: 10.1007/s10933-010-9442-4

Rasskazov A.A., Sevastyanov D.V., Egorov A.N. 1990. Composition of the lake water and mineral sediments in drainless basins of Southern Khubsugul region. Geography and Natural Resources 1: 170-174. [In Russian]

Schagerl M. (Ed.). 2016. Soda lakes of East Africa. Switzerland: Springer. $408 \mathrm{p}$.

Sevastyanov D.V. 2000. Moisture fluctuations and development of limnosystems in the Gobi Valley of lakes (Mongolia). Arid Ecosystems 6(11-12): 77-88. [In Russian]

Shadrin N.V., Anufriieva E.V. 2013. Climate change impact on the marine lakes and their crustaceans: the case of marine hypersaline Lake Bakalskoye (Ukraine). Turkish Journal of Fisheries and Aquatic Science 13(4): 603-611. DOI: 10.4194/1303-2712-v13 405

Shamsutdinov V.Kh. 1983. Peculiarities of water regime of Torey lakes. In: Nature of Tsasucheisko-Toreiskii Reserve. Chita: Transbaikal Branch of the USSR Geographical Society. P. 7-11. [In Russian]

Simonov E., Goroshko O., Egidarev E., Kiriliuk O., Kiriliuk V., Kochneva N., Obyazov V., Tkachuk T. 2013. Adaptation to climate change in the river basins of Dauria: ecology and water management. Beijing: People's Daily Press. 104 p.

Sklyarov E.V., Sklyarova O.A., Menshagin Yu.V., Danilova M.A. 2011. Mineralized lakes of the Transbaikalia and Northeastern Mongolia: specific features of occurrence and ore-generating potential. Geography and Natural Recourses 32(4): 323-332. DOI: 10.1134/ S1875372811040044

Stephens D.W. 1990. Changes in lake levels, salinity and the biological community of Great Salt Lake (Utah, USA), 1847-1987. Hydrobiologia 197(1): 139-146. DOI: 10.1007/BF00026946

Talling J.F. 2001. Environmental controls on the functioning of shallow tropical lakes. Hydrobiologia 458: 1-8. DOI: $10.1023 / \mathrm{A}: 1013121522321$

Tóth A., Horváth Z., Vad C.F., Zsuga K., Nagy S.A., Boros E. 2014. Zooplankton of the European soda pans: fauna and conservation of a unique habitat type. International Review of Hydrobiology 99(3): 255-276. DOI: 10.1002/ iroh.201301646

Tsybekmitova G.Ts. 2018. Hydrochemistry of certain lakes of the Onon-Torey High Plain. International Journal of Applied and Fundamental Research 11: 144-148. [In Russian]

Tsybekmitova G.Ts., Belozertseva I.A. 2014. Hydrochemistry of saline lakes of Onon-Borzinskoe interfluve
(Zabaykalsky Krai). Water: Chemistry and Ecology 2: 3-8. [In Russian]

Tsyrenova D.D., Bryanskaya A.V., Namsaraev B.B. 2008. Hydrobiological studies of soda-saline lakes of Transbaikalia. Bulletin of Irkutsk State University. Series Biology. Ecology 1(1): 135-138. [In Russian]

Vakhnina I.L., Noskova E.V., Golyatina M.A. 2020. Features of change in area of a water mirror and the number of lakes in the steppe zone of the Eastern Transbaikalia. Proceedings of Voronezh State University. Series: Geography. Geoecology 3: 13-23. DOI: 10.17308/ geo.2020.3/3019 [In Russian]

Vesnina L.V., Permyakova G.V., Ronzhina T.O. 2012. Biota of commercial hyperhaline lakes of the Altai Territory in transgressive and regressive phases of water availability. Bulletin of Kamchatka State Technical University 21: 24-30. [In Russian]

Vizer L.S. 2016. Zooplankton communities of saline reservoirs of the south of Western Siberia by example of Chany Lake system. Dr. Sc. Thesis. Novosibirsk. 309 p. [In Russian]

Williams W.D. 2002. Environmental threats to salt lakes and the likely status of inland saline ecosystems in 2025. Environmental Conservation 29(2): 154-167. DOI: 10.1017/S0376892902000103

Wood R.B., Talling J.F. 1988. Chemical and algal relationships in a salinity series of Ethiopian inland waters. $\mathrm{Hy}$ drobiologia 158(1): 29-67. DOI: 10.1007/BF00026266

Zadereev E. 2018. Salt lakes, surrounding environments and environmental management. In: M. Zheng, T. Deng, A. Oren (Eds.): Introduction to Salt Lake Sciences. Beijing: Science Press. P. 172-179.

Zadereev E., Lipka O., Karimov B., Krylenko M., Elias V., Pinto I.S., Alizade V., Anker Ya., Feest A., Kuznetsova D., Mader A., Salimov R., Fischer M. 2020. Overview of past, current, and future ecosystem and biodiversity trends of inland saline lakes of Europe and Central Asia. Inland Waters 10(4): 438-452. DOI: 10.1080/20442041.2020.1772034

Zakharyuk A.G., Kozyreva L.P., Egorova D.V., Namsaraev B.B. 2010. Physical and chemical and microbial characterization of sandy mate of soda Zun-Torey Lake (Transbaikalia). Bulletin of the Moscow Region State University. Series: Natural Sciences 1: 104-107. [In Russian]

Zamana L.V.2009. Formation and transformation of the chemical composition of waters of mineral lakes (the example of Transbaikalia). Doklady Earth Sciences 428(7): 1188-1191. DOI: 10.1134/S1028334X09070332

Zamana L.V., Borzenko S.V. 2010. Hydrochemical regime of saline lakes in the southeastern Transbaikalia. Geography and Natural Resources 31(4): 370-376. DOI: 10.1016/j.gnr.2010.11.011

Zamana L.V., Vakhnina I.L. 2014. Hydrochemistry of saline lakes of the southeastern Transbaikalia under climate aridization in the beginning of 20th century. International Journal of Applied and Fundamental Researches 11(4): 608-612. [In Russian] 


\title{
ТОРЕЙСКИЕ ОЗЕРА (ДАУРСКИЙ ГОСУДАРСТВЕННЫЙ ПРИРОДНЫЙ БИОСФЕРНЫЙ ЗАПОВЕДНИК, РОССИЯ): МНОГОЛЕТНИЕ ИЗМЕНЕНИЯ ПАРАМЕТРОВ СРЕДЫ
}

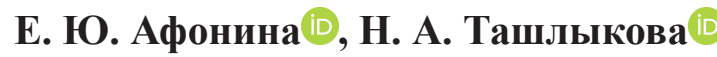 \\ Институт природных ресурсов, экологии и криологии СО РАН, Россия \\ e-mail:kataf@mail.ru,NatTash2005@yandex.ru
}

\begin{abstract}
В работе представлены результаты исследований озер Барун-Торей и Зун-Торей, характеризующихся значительными колебаниями уровня воды. Водоемы расположены в засушливой степной зоне Палеарктики, на территории Даурского государственного природного биосферного заповедника (Юго-Восточное Забайкалье, Россия), в приграничной зоне с Монголией и Китаем. Уникальной особенностью обширных по площади и мелководных Торейских озер является неустойчивый гидрологический режим. Колебания уровня воды (периодическое наполнение и высыхание) связаны с циклическими изменениями увлажненности территории и температуры. В статье приведен краткий обзор (по литературным и неопубликованным собственным данным) некоторых гидрологических и гидрохимических параметров среды озер. Торейские озера изучались спорадически в течение 20 лет. Исследованные годы были условно разделены на периоды. Для оз. Зун-Торей выделены три периода: годы с высоким (1999 и 2003 гг.), переходным (2007, 2011 гг.) и низким (2014 и 2016 гг.) уровнями воды. Для озера Барун-Торей были выделены два периода: высокий уровень воды (1999 и 2003 гг.) и фаза начального заполнения $(2014,2016,2018,2020$ гг.). Цель настоящей работы - обобщение данных по абиотическим параметрам среды Торейских озер в течение климатического цикла: высыхание - начальное заполнение. Варьирование уровня воды влекут за собой и изменения в некоторых гидрофизических и гидрохимических параметрах среды. По мере высыхания озера Зун-Торей происходит увеличение концентрации растворенных солей, $\mathrm{pH}$ и температуры воды. Воды озера БарунТорей (как и озера Зун-Торей) в годы с высоким уровнем воды характеризуются как олигогалинные и с высокими показателями рН. В начальный период наполнения, мелкие водоемы, расположенные в котловине Барун-Торея, относятся к пресным водам, образованные в результате выхода грунтовых вод и выпадения атмосферных осадков.
\end{abstract}

Ключевые слова: абиотические показатели среды, Барун-Торей, гидрологический цикл, Даурский государственный природный биосферный заповедник, Зун-Торей, уровень воды 